\title{
Electrocautery-induced gangrene of the glans penis in a child following circumcision
}

\author{
Gunalp Uzun, ${ }^{1}$ Yavuz Ozdemir, ${ }^{2}$ Murat Eroglu, ${ }^{3}$ Mesut Mutluoglu ${ }^{1}$ \\ ${ }^{1}$ Department of Underwater and Hyperbaric Medicine, Gulhane Military Medical Academy Haydarpasa Teaching Hospital, Istanbul, Turkey \\ ${ }^{2}$ Department of General Surgery, Gulhane Military Medical Academy Haydarpasa Teaching Hospital, Istanbul, Turkey \\ ${ }^{3}$ Department of Emergency Medicine, Gulhane Military Medical Academy Haydarpasa Teaching Hospital, Istanbul, Turkey
}

Correspondence to Dr Mesut Mutluoglu, drmutluoglu@gmail.com

\section{DESCRIPTION}

A 7-year-old child was brought to the hyperbaric oxygen centre because of cyanosis of his glans penis. He had been circumcised the same day with the use of a monopolar electrocautery device. Unfortunately, the electrocautery caused a severe burn injury on the glans of the child. On examination, he had necrosis over the glans and shaft of the penis (figure 1).

Circumcision is a religious and traditional ritual in some cultures and involves the removal of the preputium penis. It may be performed by a variety of techniques, and although it is regarded as a relatively safe procedure, it does, like any surgical procedure, carry the risk of complications. Choosing the most appropriate technique and giving the highest attention and care will avoid most of these complications. Bipolar electrocautery has been shown to be safe in circumcision. ${ }^{1}$ However, the use of a monopolar electrocautery, as was the case in this patient, has resulted in a dramatic accident. Indeed, when a monopolar electrode is used, the electrical current is carried by the small diameter of the penis, which may lead to tissue heating and thus thermal injury. ${ }^{2}$ Although adjunctive

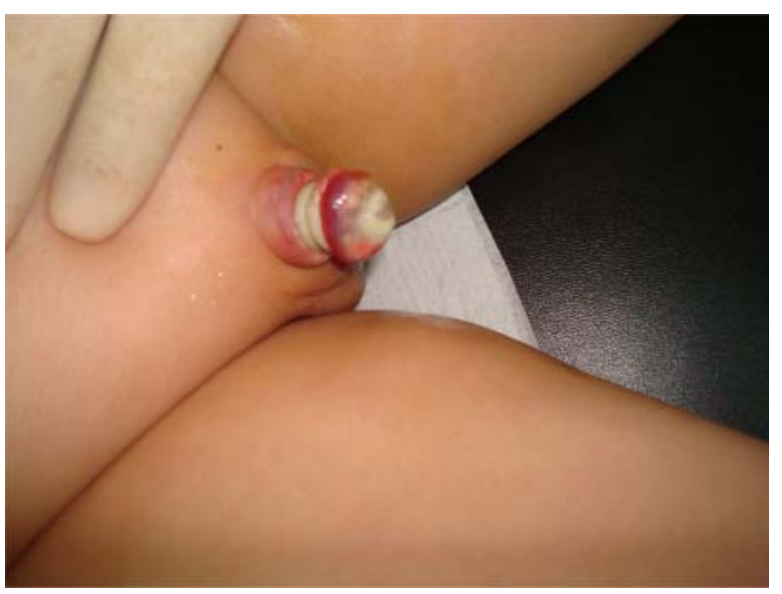

Figure 1 Necrosis of glans and penile shaft.

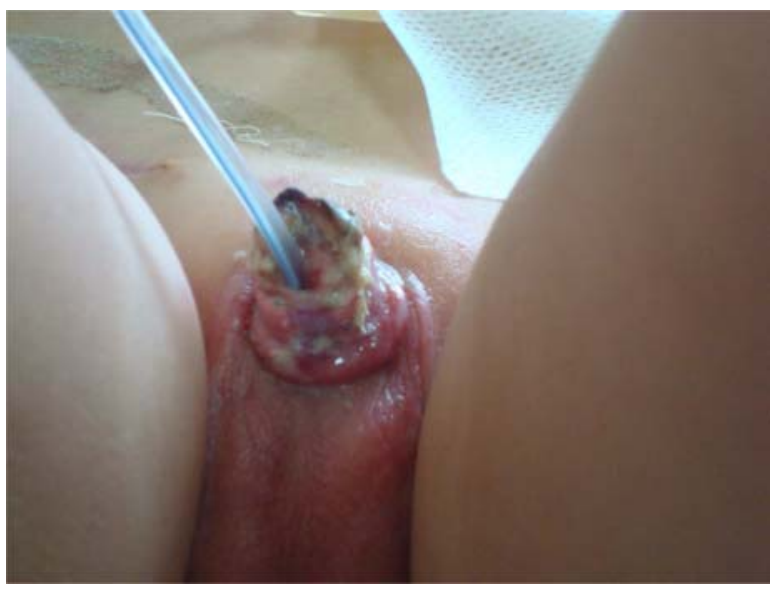

Figure 2 Despite hyperbaric oxygen therapy and wound care, debridement was unavoidable.

hyperbaric oxygen therapy was administered in the following days, the lesion worsened and resulted in significant tissue loss involving the whole glans and the distal parts of the penile shaft (figure 2).

\section{Learning points}

- Monopolar electrocautery should be avoided in circumcision.

- Choosing the proper technique minimises complication ratio in circumcision.

Competing interests None.

Patient consent Obtained.

\section{REFERENCES}

1. Peters RT, Fisher R. Paediatric circumcision using bipolar diathermy. Ann $R$ Coll Surg Engl 2009;91:436.

2. Geddes LA. Medical device accidents and illustrative cases. Tucson:Lawyers and Judges Publishing Company;2002. 


\section{BMJ Case Reports}

Copyright 2012 BMJ Publishing Group. All rights reserved. For permission to reuse any of this content visit http://group.bmj.com/group/rights-licensing/permissions.

BMJ Case Report Fellows may re-use this article for personal use and teaching without any further permission.

Please cite this article as follows (you will need to access the article online to obtain the date of publication).

Uzun G, Ozdemir Y, Eroglu M, Mutluoglu M. Electrocautery-induced gangrene of the glans penis in a child following circumcision. BMJ Case Reports 2012;10.1136/bcr-2012-007096, Published XXX

Become a Fellow of BMJ Case Reports today and you can:

- Submit as many cases as you like

- Enjoy fast sympathetic peer review and rapid publication of accepted articles

- Access all the published articles

- Re-use any of the published material for personal use and teaching without further permission

For information on Institutional Fellowships contact consortiasales@bmjgroup.com

Visit casereports.bmj.com for more articles like this and to become a Fellow 